\title{
Water Resources of West Carroll Parish, Louisiana
}

\section{Introduction}

Information concerning the availability, use, and quality of water in West Carroll Parish, Louisiana (fig. 1), is critical for proper water-supply management. The purpose of this fact sheet is to present information that can be used by water managers, parish residents, and others for stewardship of this vital resource. In 2014, 21.27 million gallons per day (Mgal/d) of water were withdrawn in West Carroll Parish, including $17.91 \mathrm{Mgal} / \mathrm{d}$ from groundwater sources and 3.37 Mgal/d from surface-water sources ${ }^{1}$ (table 1). Withdrawals for

${ }^{1}$ Water-withdrawal data are based on estimated or reported site-specific data and aggregated data, which are distributed to sources. For a full description of water-use estimate methodology, see "Data Collection" in Sargent (2011). Tabulation of numbers in text and tables may result in different totals because of rounding; nonrounded numbers are used for calculation of totals.

\section{Groundwater Resources}

The primary freshwater-bearing aquifers in West Carroll Parish are the Mississippi River alluvial aquifer (called the Mississippi River Valley alluvial aquifer in some publications) (fig. 3) and the Cockfield aquifer (figs. 1 and 3). The base of fresh groundwater (water with a chloride concentration of 250 milligrams per liter $[\mathrm{mg} / \mathrm{L}]$ or less) ranges from less than 100 feet (ft) below the National Geodetic Vertical Datum of 1929 (NGVD 29) in the northeastern part of the parish to agricultural use, composed of general irrigation, rice irrigation, and livestock, accounted for 93 percent $(19.76 \mathrm{Mgal} / \mathrm{d})$ of the total water withdrawn (table 2). Other use categories included public supply and rural domestic. Water-use data collected at 5-year intervals from 1960 to 2010 and again in 2014 indicated that water withdrawals peaked in 2000 at $31.7 \mathrm{Mgal} / \mathrm{d}$ (fig. 2). The large decreases in water use from 1985 to 1990 and again from 2005 to 2010 are primarily attributable to declines in groundwater withdrawals for rice irrigation from $10 \mathrm{Mgal} / \mathrm{d}$ in 1985 to $2.22 \mathrm{Mgal} / \mathrm{d}$ in 1990 and from $10.52 \mathrm{Mgal} / \mathrm{d}$ in 2005 to $5.14 \mathrm{Mgal} / \mathrm{d}$ in 2010 (U.S. Geological Survey [USGS], 2016b). Surface-water withdrawals for general irrigation declined from $2.44 \mathrm{Mgal} / \mathrm{d}$ in 1985 to $0.42 \mathrm{Mgal} / \mathrm{d}$ in 1990 and from $2.2 \mathrm{Mgal} / \mathrm{d}$ in 2005 to $1.1 \mathrm{Mgal} / \mathrm{d}$ in 2010. Surface-water withdrawals for rice irrigation declined from $1.41 \mathrm{Mgal} / \mathrm{d}$ in 1985 to $0.66 \mathrm{Mgal} / \mathrm{d}$ in 1990 and from $2.06 \mathrm{Mgal} / \mathrm{d}$ in 2005 to $1.01 \mathrm{Mgal} / \mathrm{d}$ in 2010 .

greater than $300 \mathrm{ft}$ below NGVD 29 in the southern part of the parish in the Cockfield aquifer (fig. 1) (Smoot, 1988).

\section{Mississippi River Alluvial Aquifer}

The Mississippi River alluvial aquifer, which extends across West Carroll Parish, is a large regional aquifer that is present in various States (Saucier, 1994). The Mississippi River alluvial aquifer is composed of the sand-and-gravel part of the alluvial sediments deposited primarily by the Mississippi River. These

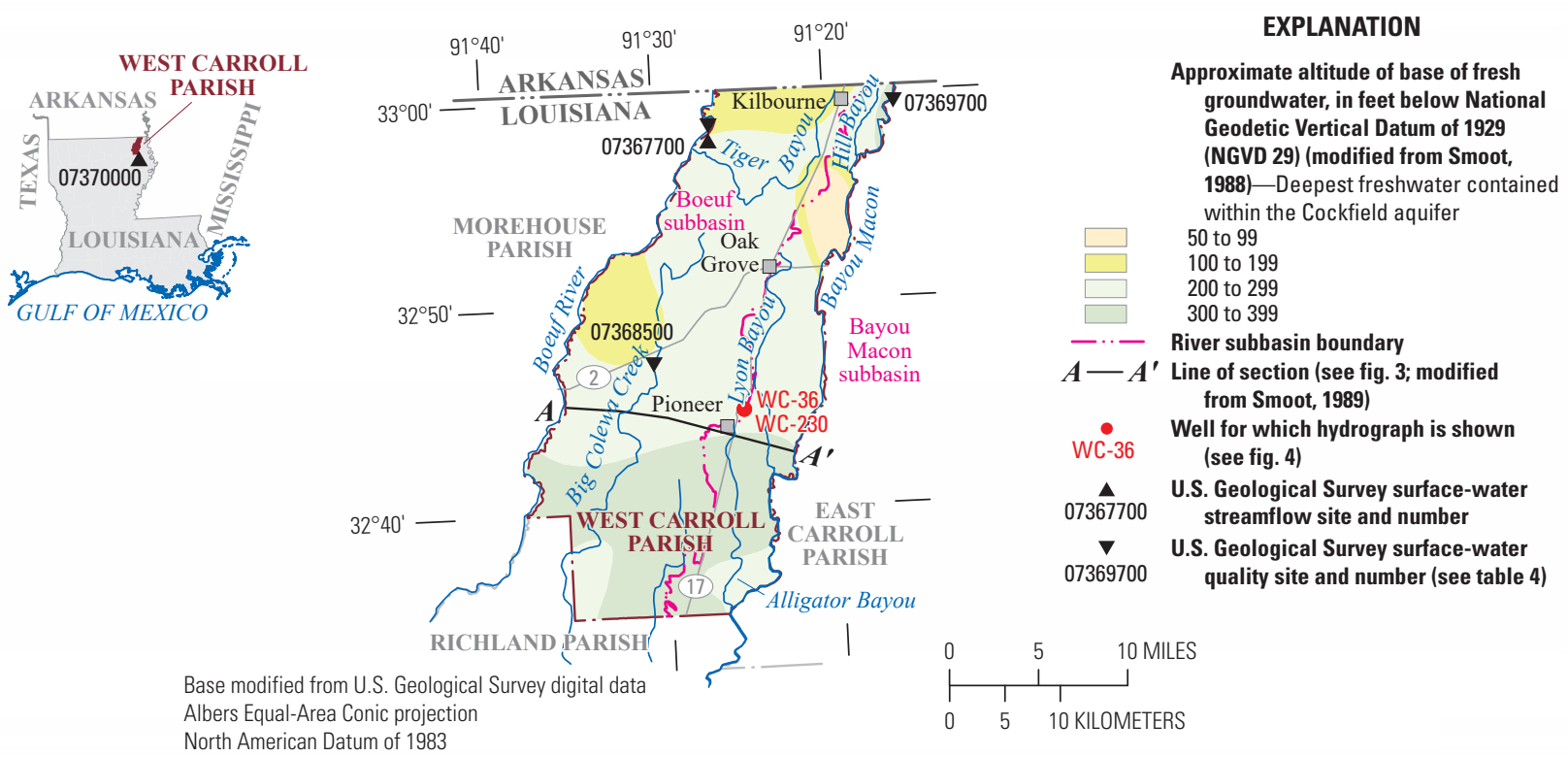

Figure 1. Location of study area, West Carroll Parish, Louisiana. 
Table 1. Water withdrawals, in million gallons per day, by source in West Carroll Parish, Louisiana, 2014 (Collier, 2018).

\begin{tabular}{lcc}
\hline $\begin{array}{c}\text { Aquifer or } \\
\text { surface-water body }\end{array}$ & Groundwater & Surface water \\
\hline $\begin{array}{c}\text { Mississippi River } \\
\text { alluvial aquifer }\end{array}$ & 16.89 & \\
Cockfield aquifer & 1.01 & \\
Bayou Macon & & 2.01 \\
Miscellaneous surface & & 1.36 \\
$\quad$ waters & & \\
Total & $\mathbf{1 7 . 9 1}$ & $\mathbf{3 . 3 7}$ \\
\hline
\end{tabular}

Table 2. Water withdrawals, in million gallons per day, by use category in West Carroll Parish, Louisiana, 2014 (Collier, 2018).

$[<$, less than $]$

\begin{tabular}{lccc}
\hline \multicolumn{1}{c}{ Use category } & Groundwater & Surface water & Total \\
\hline Public supply & 1.44 & 0.00 & 1.44 \\
Rural domestic & 0.07 & 0.00 & 0.07 \\
Livestock & $<0.01$ & $<0.01$ & $<0.01$ \\
Rice irrigation & 3.03 & 1.01 & 4.04 \\
General irrigation & 13.36 & 2.36 & 15.72 \\
\cline { 2 - 4 } Total & $\mathbf{1 7 . 9 1}$ & $\mathbf{3 . 3 7}$ & $\mathbf{2 1 . 2 7}$ \\
\hline
\end{tabular}

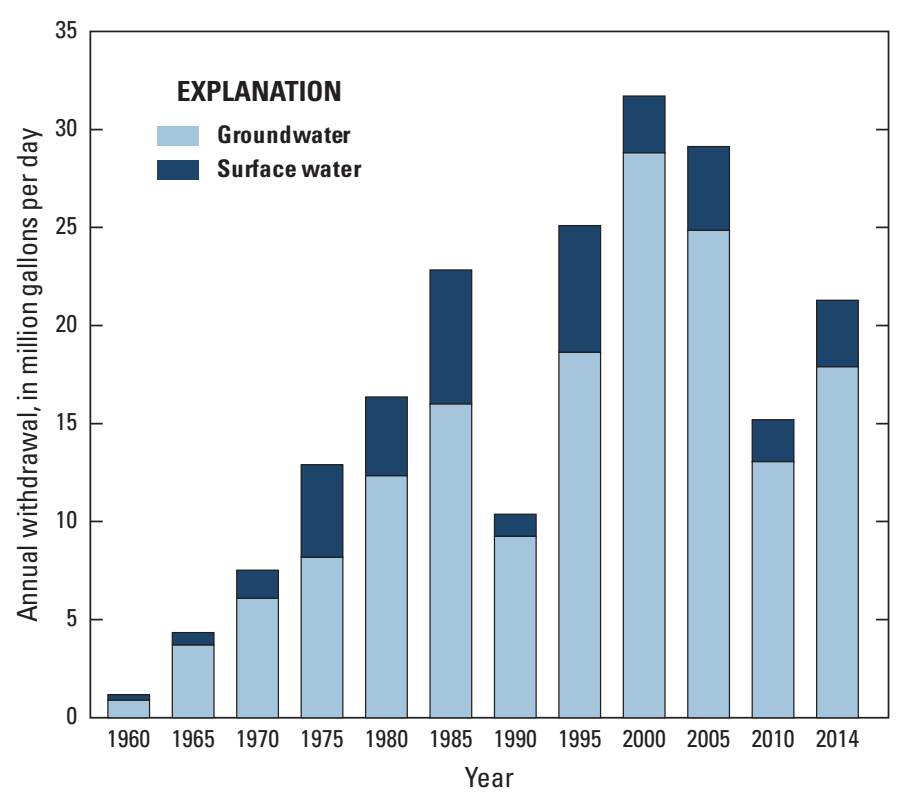

Figure 2. Water withdrawals in West Carroll Parish, Louisiana, 1960-2014 (U.S. Geological Survey, 2016b; Collier, 2018).

deposits generally grade from silt and clay at land surface to coarse sand and gravel at the base. The thickness of the Mississippi River alluvial deposit ranges from less than $100 \mathrm{ft}$ in the northern part of the parish to greater than $140 \mathrm{ft}$ in the southeastern part. The altitude of the base of the aquifer ranges from greater than NGVD 29 in the northern part of the parish to greater than $60 \mathrm{ft}$ below NGVD 29 in the southeastern part (Whitfield, 1975).
The primary source of recharge to the alluvial aquifer is the infiltration of precipitation, with secondary sources of recharge from streams and rivers during high stage. Groundwater in the alluvial aquifer generally flows southward but also moves westward towards the Boeuf River in the western part of the parish and eastward towards Bayou Macon in the eastern part of the parish (fig. 1). Groundwater discharge is by evapotranspiration, natural flow into streams and rivers, and well withdrawals (Whitfield, 1975). Well withdrawal rates can affect the direction of groundwater flow either locally or regionally.

In 1990, a regional survey of water-level altitudes indicated that levels in wells screened in the Mississippi River alluvial aquifer ranged from greater than $80 \mathrm{ft}$ above NGVD 29 in the northern part of the parish to less than $70 \mathrm{ft}$ above NGVD 29 in the southeastern part of the parish (Seanor and Smoot, 1995). Water levels at well WC-230 (USGS site number 324508091252302), located northeast of Pioneer (fig. 1), fluctuated between about 74 and $78 \mathrm{ft}$ above NGVD 29 from the mid-1950s to the mid-1990s, but declined about $6 \mathrm{ft}$ from the mid-1990s to 2016 (fig. 4). Overall groundwater use increased from 1995 to 2005 and declined from 2005 to 2014. Groundwater levels at WC-230 appear to be stabilizing from 2014 to 2016.

State well-registration records listed 752 active water wells screened in the Mississippi River alluvial aquifer in West Carroll Parish in 2016: 650 irrigation wells, 91 domestic wells, 6 publicsupply wells, and 5 industrial wells. Well depths ranged from 19 to $140 \mathrm{ft}$ below land surface, and reported yields ranged from 9 to 4,000 gallons per minute (gal $/ \mathrm{min}$ ) (Louisiana Department of Natural Resources, 2016). In 2014, about $16.89 \mathrm{Mgal} / \mathrm{d}$ were withdrawn from the Mississippi River alluvial aquifer: $0.07 \mathrm{Mgal} / \mathrm{d}$ for rural domestic, $13.36 \mathrm{Mgal} / \mathrm{d}$ for general irrigation, less than $0.01 \mathrm{Mgal} / \mathrm{d}$ for livestock, $3.03 \mathrm{Mgal} / \mathrm{d}$ for rice irrigation, and $0.44 \mathrm{Mgal} / \mathrm{d}$ for public supply (Collier, 2018).

\section{Cockfield Aquifer}

The Cockfield aquifer is a regional aquifer that contains freshwater in much of northeastern and parts of west-central Louisiana (Brantly and Seanor, 1996). The aquifer is composed of sands and silts interbedded with discontinuous layers of clay and lignite. Sands range from very fine to medium grained. The layers of the aquifer dip in a southeasterly direction. The altitude of the base of the Cockfield aquifer ranges from about $250 \mathrm{ft}$ below NGVD 29 in the western part of the parish to greater than $350 \mathrm{ft}$ below NGVD 29 in the eastern part (Poole, 1961). The Mississippi River alluvial aquifer unconformably overlies the Cockfield aquifer throughout West Carroll Parish (fig. 3), and the aquifers are in direct hydraulic connection. The hydraulic connection allows the Mississippi River alluvial aquifer to recharge the Cockfield aquifer (Brantly and Seanor, 1996). Freshwater is available from the Cockfield aquifer throughout the parish (Smoot, 1988).

In 1993, a study of water-level altitudes in wells screened in the Cockfield aquifer indicated that levels were between $90 \mathrm{ft}$ above NGVD 29 in the northern part of the parish and about $72 \mathrm{ft}$ above NGVD 29 in the southern part of the parish with flow generally toward the south-southwest (Brantly and Seanor, 1996). Water levels at well WC-36 (USGS site number 324508091252301), located northeast of Pioneer (fig. 1), mimicked water levels in the overlying alluvial aquifer because 


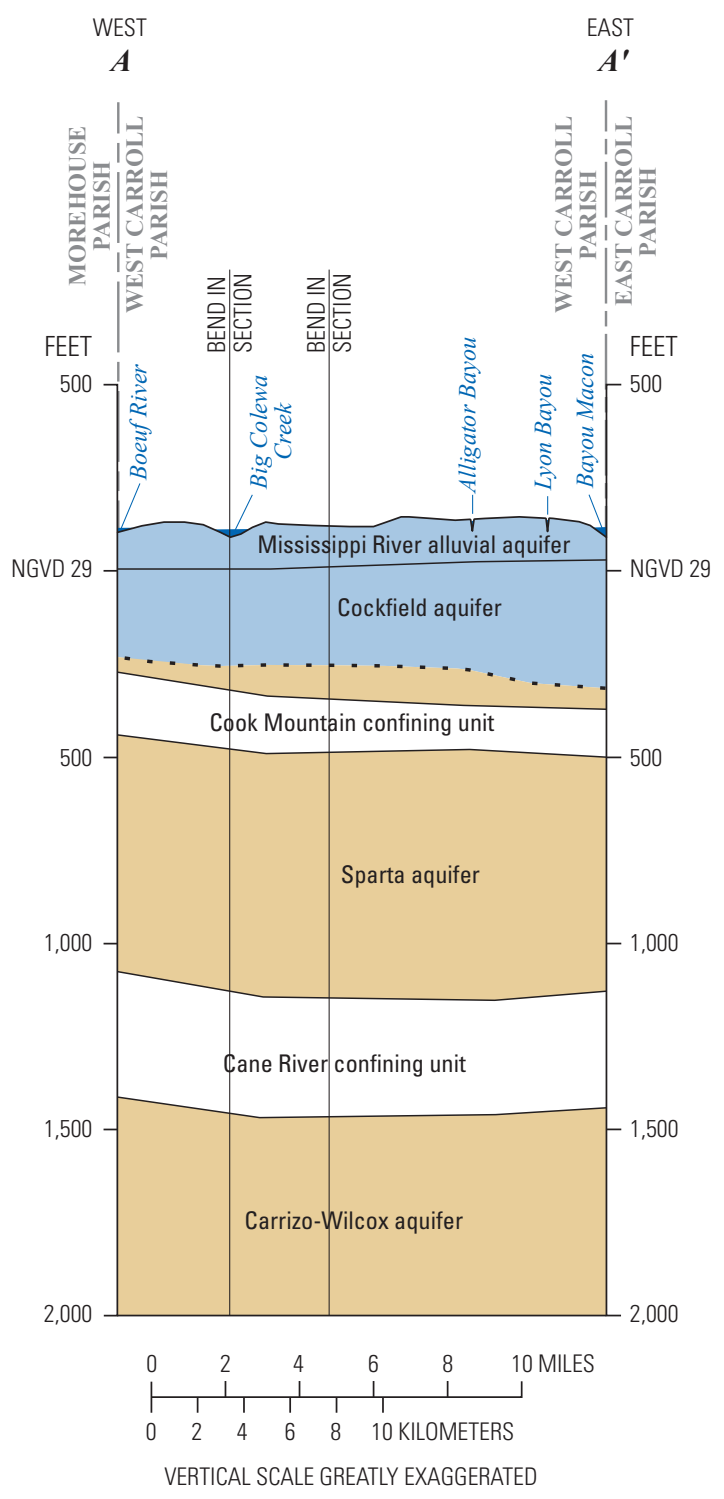

EXPLANATION

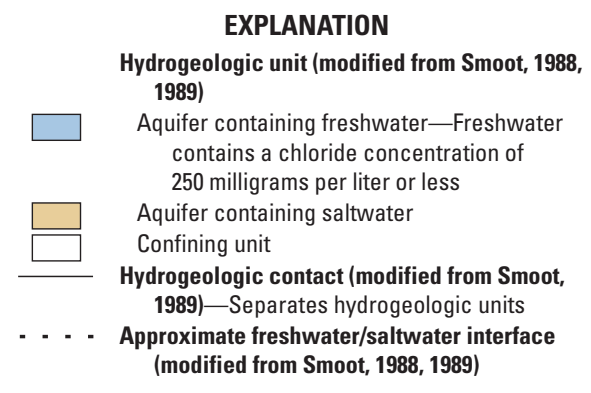

NGVD 29, National Geodetic Vertical Datum of 1929

Figure 3. Idealized west-to-east hydrogeologic section through West Carroll Parish, Louisiana, showing aquifer and confining unit intervals (individual sand and clay layers not shown). Trace of section shown on figure 1 .

of hydraulic connection, declining about $6 \mathrm{ft}$ from the early 1990s to 2016 (fig. 4).

State well-registration records listed 31 active water wells screened in the Cockfield aquifer in West Carroll Parish in 2016: 6 domestic wells, 24 public-supply wells, and 1 industrial well. Well depths ranged from 145 to $462 \mathrm{ft}$ below land surface, and reported yields ranged from 10 to $500 \mathrm{gal} / \mathrm{min}$ (Louisiana
Department of Natural Resources, 2016). In 2014, more than 1.01 $\mathrm{Mgal} / \mathrm{d}$ were withdrawn from the Cockfield aquifer, with use categories including less than $0.01 \mathrm{Mgal} / \mathrm{d}$ for rural domestic and $1.01 \mathrm{Mgal} / \mathrm{d}$ for public supply (Collier, 2018).

\section{Groundwater Quality}

Groundwater samples were collected from 35 wells screened in the Mississippi River alluvial aquifer during 1941-2011 and from 34 wells screened in the Cockfield aquifer during 1941-84 as part of an ongoing program to monitor the State's groundwater resources. These samples were within the U.S. Environmental Protection Agency's Secondary Maximum Contaminant Levels ${ }^{2}$ (SMCLs) for $\mathrm{pH}$ (6.5-8.5 standard units) and sulfate concentrations $(250 \mathrm{mg} / \mathrm{L})$ (table 3$)$. The median hardness value of $398 \mathrm{mg} / \mathrm{L}$ as calcium carbonate for the Mississippi River alluvial aquifer and $195 \mathrm{mg} / \mathrm{L}$ as calcium carbonate for the Cockfield aquifer were within the very $\operatorname{hard}^{3}$ range. Median concentrations of iron and manganese exceeded the SMCLs (300 micrograms per liter $[\mu \mathrm{g} / \mathrm{L}]$ ) and $50 \mu \mathrm{g} / \mathrm{L}$, respectively) for both aquifers. The median dissolvedsolids concentration was below the SMCL $(500 \mathrm{mg} / \mathrm{L})$ for the Mississippi River alluvial aquifer and slightly exceeded the SMCL for the Cockfield aquifer.

\section{Surface-Water Resources}

Numerous surface-water resources are present in West Carroll Parish in primarily two drainage subbasins (fig. 1). The Boeuf subbasin (Hydrologic Unit Code [HUC] 08050001) drains the western part of the parish, and the Bayou Macon subbasin (HUC 08050002) drains the eastern part of the parish (USGS, 2016a). In 2014, $1.36 \mathrm{Mgal} / \mathrm{d}$ were withdrawn from miscellaneous streams: less than $0.01 \mathrm{Mgal} / \mathrm{d}$ for livestock, $0.94 \mathrm{Mgal} / \mathrm{d}$ for general irrigation, and $0.41 \mathrm{Mgal} / \mathrm{d}$ for rice irrigation (tables 1-2) (Collier, 2018).

\section{Boeuf Subbasin}

The Boeuf River is the primary river draining the Boeuf subbasin in West Carroll Parish. The Boeuf River enters Louisiana from Arkansas and flows in a southerly direction along much of the western border of the parish. Many other streams are present in the subbasin, including Big Colewa Creek ${ }^{4}$ and Tiger Bayou (fig. 1). The average of daily mean streamflow values for the Boeuf River near AR/LA State Line (USGS site number 07367700) was about 347 cubic feet per second $\left(\mathrm{ft}^{3} / \mathrm{s}\right)$ during 1986-2012 from a drainage area of 785 square miles $\left(\mathrm{mi}^{2}\right)$.

${ }^{2}$ The SMCLs are Federal guidelines regarding cosmetic effects (such as tooth or skin discoloration), aesthetic effects (such as taste, odor, or color), or technical effects (such as damage to water equipment or reduced effectiveness of treatment for other contaminants) of potential constituents of drinking water. SMCLs were established as guidelines by the U.S. Environmental Protection Agency (2016).

${ }^{3}$ Hardness ranges, expressed as milligrams per liter of calcium carbonate, are as follows: 0-60, soft; 61-120, moderately hard; $121-180$, hard; greater than 180, very hard (Hem, 1985).

${ }^{4}$ USGS topographic map presents the upper reaches of Big Colewa Creek under the name Big Colewa Bayou; other publications may also use this naming convention. 
Table 3. Summary of selected water-quality characteristics for 35 freshwater wells screened in the Mississippi River alluvial aquifer and 34 freshwater wells screened in the Cockfield aquifer in West Carroll Parish, Louisiana (U.S. Geological Survey, 2016a).

[Values are in milligrams per liter, except as noted. ${ }^{\circ} \mathrm{C}$, degrees Celsius; $\mu \mathrm{S} / \mathrm{cm}$, microsiemens per centimeter; $\mathrm{SU}$, standard unit; $\mathrm{CaCO}_{3}$, calcium carbonate; $\mu \mathrm{g} / \mathrm{L}$, micrograms per liter; SMCL, Secondary Maximum Contaminant Level established by the U.S. Environmental Protection Agency (2016); NA, not applicable]

\begin{tabular}{|c|c|c|c|c|c|c|c|c|c|c|c|c|c|}
\hline & $\begin{array}{l}\text { Tem- } \\
\text { perature } \\
\left({ }^{\circ} \mathrm{C}\right)\end{array}$ & $\begin{array}{l}\text { Color } \\
\text { (plati- } \\
\text { num } \\
\text { cobalt } \\
\text { units) }\end{array}$ & $\begin{array}{l}\text { Specific } \\
\text { conduc- } \\
\text { tance, } \\
\text { field } \\
(\mu \mathrm{S} / \mathrm{cm} \text { at } \\
\left.25^{\circ} \mathrm{C}\right)\end{array}$ & $\begin{array}{l}\text { pH, field } \\
\text { (SU) }\end{array}$ & $\begin{array}{l}\text { Hardness } \\
\text { (as } \mathrm{CaCO}_{3} \text { ) }\end{array}$ & $\begin{array}{l}\text { Cal- } \\
\text { cium, } \\
\text { filtered } \\
\text { (as Ca) }\end{array}$ & $\begin{array}{c}\text { Mag- } \\
\text { nesium, } \\
\text { filtered } \\
\text { (as Mg) }\end{array}$ & $\begin{array}{l}\text { So- } \\
\text { dium, } \\
\text { filtered } \\
\text { (as } \mathrm{Na)}\end{array}$ & $\begin{array}{l}\text { Chlo- } \\
\text { ride, } \\
\text { filtered } \\
\text { (as CI) }\end{array}$ & $\begin{array}{l}\text { Sulfate, } \\
\text { filtered } \\
\text { (as } \mathrm{SO}_{4} \text { ) }\end{array}$ & $\begin{array}{l}\text { Iron, } \\
\text { filtered, } \\
\text { in } \mu g / L \\
\text { (as Fe) }\end{array}$ & $\begin{array}{c}\text { Man- } \\
\text { ganese, } \\
\text { filtered, } \\
\text { in } \mu \mathrm{g} / \mathrm{L} \\
\text { (as Mn) }\end{array}$ & $\begin{array}{l}\text { Dis- } \\
\text { solved } \\
\text { solids, } \\
\text { filtered }\end{array}$ \\
\hline \multicolumn{14}{|c|}{ Mississippi River alluvial aquifer (1941-2011) } \\
\hline Median & 19.6 & 5 & 916 & 7.4 & 398 & 100 & 43 & 41 & 60 & 18 & 940 & 278 & 406 \\
\hline 10th percentile & 19.0 & 0 & 430 & 6.9 & 108 & 71.8 & 26.8 & 20.6 & 13.9 & 2.8 & 94 & 51.2 & 221 \\
\hline 90th percentile & 20.3 & 10 & 1,300 & 7.9 & 515 & 132 & 53 & 81.4 & 191 & 62.4 & 4,660 & 543 & 714 \\
\hline $\begin{array}{c}\text { Number of } \\
\text { samples }\end{array}$ & 32 & 8 & 28 & 18 & 29 & 19 & 19 & 9 & 35 & 19 & 15 & 15 & 15 \\
\hline $\begin{array}{l}\text { Percentage of } \\
\text { samples that } \\
\text { do not exceed } \\
\text { SMCLs }\end{array}$ & NA & 100 & NA & 100 & NA & NA & NA & NA & 100 & 100 & 27 & 13 & 60 \\
\hline \multicolumn{14}{|c|}{ Cockfield aquifer (1941-84) } \\
\hline Median & 21 & 5 & 854 & 7.6 & 195 & 53.5 & 17.5 & 100 & 78 & 0.2 & 725 & 130 & 502 \\
\hline 10th percentile & 20.5 & 5 & 684 & 7.2 & 19.5 & 4.9 & 2.6 & 38 & 26.7 & 0 & 249 & 10 & 369 \\
\hline 90th percentile & 22 & 20 & 1,200 & 8.24 & 360 & 84.9 & 32.9 & 260 & 145 & 8.6 & 1,620 & 280 & 628 \\
\hline $\begin{array}{c}\text { Number of } \\
\text { samples }\end{array}$ & 21 & 31 & 32 & 34 & 38 & 32 & 32 & 31 & 38 & 33 & 30 & 11 & 29 \\
\hline $\begin{array}{l}\text { Percentage of } \\
\text { samples that } \\
\text { do not exceed } \\
\text { SMCLs }\end{array}$ & NA & 87 & NA & 100 & NA & NA & NA & NA & 100 & 100 & 17 & 18 & 48 \\
\hline SMCLs & NA & 15 & NA & $6.5-8.5$ & NA & NA & NA & NA & 250 & 250 & 300 & 50 & 500 \\
\hline
\end{tabular}

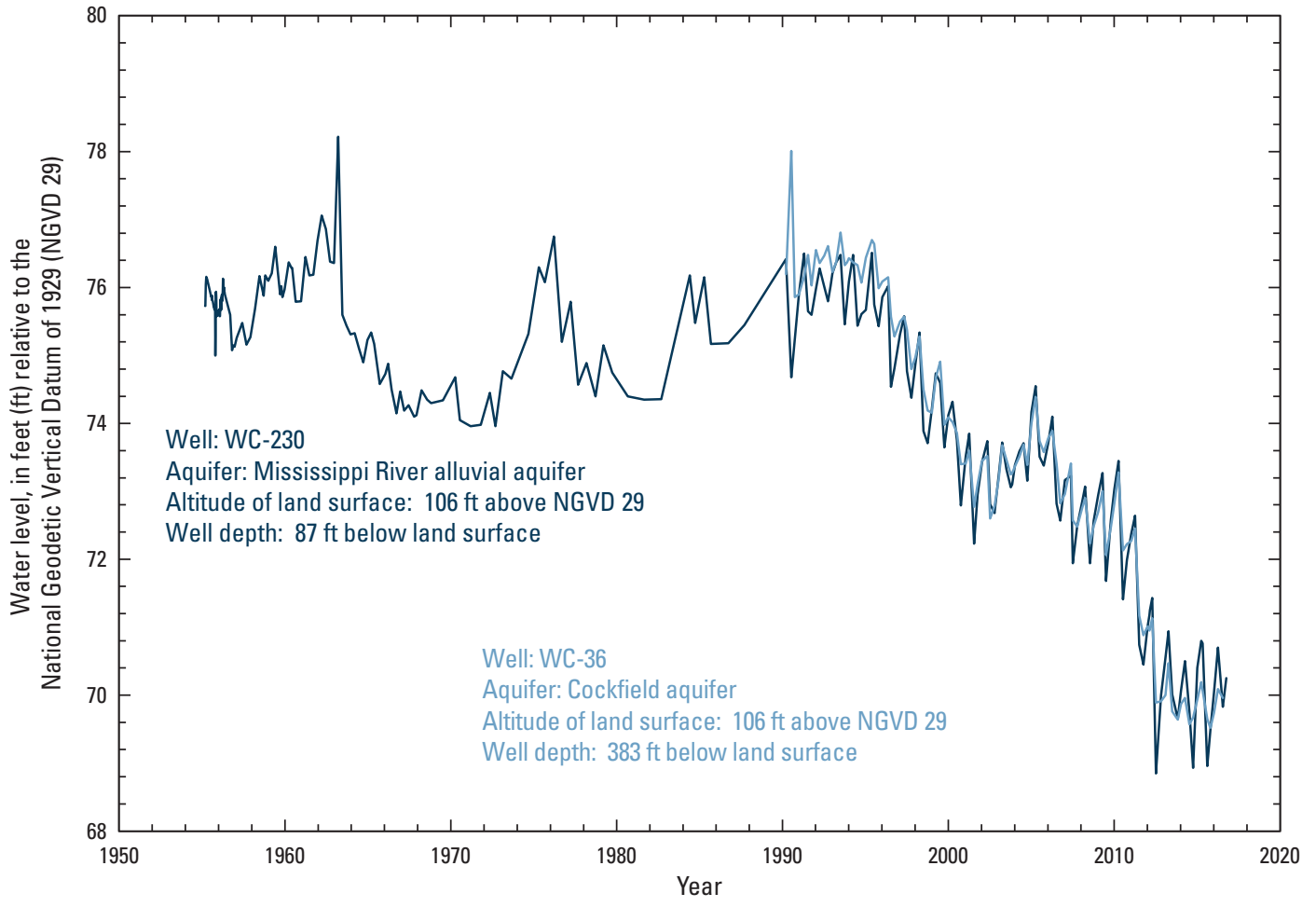

Figure 4. Water levels in well WC-230 screened in the Mississippi River alluvial aquifer and well WC-36 screened in the Cockfield aquifer in West Carroll Parish, Louisiana (see fig. 1 for well location; U.S. Geological Survey, 2016a). 
Table 4. Summary of selected water-quality characteristics for samples from Big Colewa Creek, Bayou Macon, and Boeuf River, West Carroll Parish, Louisiana (U.S. Geological Survey, 2016a).

[Values are in milligrams per liter, except as noted. ${ }^{\circ} \mathrm{C}$, degrees Celsius; $\mu \mathrm{S} / \mathrm{cm}$, microsiemens per centimeter; $\mathrm{SU}$, standard unit; $\mathrm{CaCO}_{3}$, calcium carbonate; $\mu \mathrm{g} / \mathrm{L}$, micrograms per liter; SMCL, Secondary Maximum Contaminant Level established by the U.S. Environmental Protection Agency (2016); NA, not applicable; <, less than; USGS, U.S. Geological Survey]

\begin{tabular}{|c|c|c|c|c|c|c|c|c|c|c|c|}
\hline & $\begin{array}{l}\text { Tem- } \\
\text { perature } \\
\left({ }^{\circ} \mathrm{C}\right)\end{array}$ & $\begin{array}{l}\text { Color } \\
\text { (platinum } \\
\text { cobalt } \\
\text { units) }\end{array}$ & $\begin{array}{l}\text { Specific } \\
\text { conduc- } \\
\text { tance, } \\
\text { field } \\
(\mu \mathrm{S} / \mathrm{cm} \text { at } \\
25^{\circ} \mathrm{C} \text { ) }\end{array}$ & $\begin{array}{l}\text { pH, } \\
\text { field } \\
\text { (SU) }\end{array}$ & $\begin{array}{l}\text { Hardness } \\
\text { (as } \mathrm{CaCO}_{3} \text { ) }\end{array}$ & $\begin{array}{l}\text { Calcium, } \\
\text { filtered } \\
\text { (as Ca) }\end{array}$ & $\begin{array}{l}\text { Mag- } \\
\text { nesium, } \\
\text { filtered } \\
\text { (as Mg) }\end{array}$ & $\begin{array}{l}\text { Sodium, } \\
\text { filtered } \\
\text { (as Na) }\end{array}$ & $\begin{array}{l}\text { Chloride, } \\
\text { filtered } \\
\text { (as CI) }\end{array}$ & $\begin{array}{l}\text { Sulfate, } \\
\text { filtered } \\
\text { (as } \mathrm{SO}_{4} \text { ) }\end{array}$ & $\begin{array}{l}\text { Dis- } \\
\text { solved } \\
\text { solids, } \\
\text { filtered }\end{array}$ \\
\hline \multicolumn{12}{|c|}{ Big Colewa Creek near Oak Grove (1956-67) ${ }^{1}$} \\
\hline Median & 17.2 & NA & 58 & 6.3 & 15 & 4 & 1.4 & 2.7 & 3.1 & 2 & NA \\
\hline 10th percentile & 10.1 & NA & 42 & 5.6 & 11.6 & 3.5 & 0.5 & 1.4 & 1.1 & 1.1 & NA \\
\hline 90th percentile & 20.3 & NA & 74 & 6.6 & 26.8 & 6.2 & 2.2 & 3.5 & 5.6 & 6.8 & NA \\
\hline $\begin{array}{c}\text { Number of } \\
\text { samples }\end{array}$ & 3 & 3 & 17 & 17 & 17 & 15 & 15 & 16 & 15 & 17 & 3 \\
\hline $\begin{array}{l}\text { Percentage of } \\
\text { samples that } \\
\text { do not exceed } \\
\text { SMCLs }\end{array}$ & NA & 0 & NA & 29 & NA & NA & NA & NA & 100 & 100 & 100 \\
\hline \multirow[t]{2}{*}{ SMCLs } & NA & 15 & NA & $6.5-8.5$ & NA & NA & NA & NA & 250 & 250 & 500 \\
\hline & $\begin{array}{l}\text { Tem- } \\
\text { perature } \\
\left({ }^{\circ} \mathrm{C}\right)\end{array}$ & $\begin{array}{l}\text { Color } \\
\text { (platinum } \\
\text { cobalt } \\
\text { units) }\end{array}$ & $\begin{array}{c}\text { Specific } \\
\text { conduc- } \\
\text { tance, } \\
\text { field } \\
(\mu \mathrm{S} / \mathrm{cm} \text { at } \\
\left.25^{\circ} \mathrm{C}\right)\end{array}$ & $\begin{array}{l}\text { Dis- } \\
\text { solved } \\
\text { oxygen }\end{array}$ & $\begin{array}{l}\text { pH, field } \\
\text { (SU) }\end{array}$ & $\begin{array}{l}\text { Hardness } \\
\text { (as } \mathrm{CaCO}_{3} \text { ) }\end{array}$ & $\begin{array}{l}\text { Chloride, } \\
\text { filtered } \\
\text { (as CI) }\end{array}$ & $\begin{array}{l}\text { Sulfate, } \\
\text { filtered } \\
\text { (as } \mathrm{SO}_{4} \text { ) }\end{array}$ & $\begin{array}{l}\text { Iron, } \\
\text { filtered, } \\
\text { in } \mu \mathrm{g} / \mathrm{L} \\
\text { (as Fe) }\end{array}$ & $\begin{array}{l}\text { Man- } \\
\text { ganese, } \\
\text { filtered, } \\
\text { in } \mu \mathrm{g} / \mathrm{L} \\
\text { (as Mn) }\end{array}$ & $\begin{array}{l}\text { Dis- } \\
\text { solved } \\
\text { solids, } \\
\text { filtered }\end{array}$ \\
\hline \multicolumn{12}{|c|}{ Bayou Macon near Kilbourne (1957-91)² } \\
\hline Median & 18 & 15 & 290 & 7.8 & 7.3 & 120 & 13.5 & 15 & 50 & 50 & 186 \\
\hline 10th percentile & 7 & 5 & 124 & 6.1 & 6.7 & 52 & 4.9 & 7.4 & $<10$ & 18 & 110 \\
\hline 90th percentile & 29 & 60 & 421 & 10.9 & 7.9 & 170 & 25.9 & 24 & 220 & 144 & 247 \\
\hline $\begin{array}{c}\text { Number of } \\
\text { samples }\end{array}$ & 104 & 86 & 112 & 58 & 113 & 101 & 114 & 102 & 8 & 9 & 82 \\
\hline $\begin{array}{l}\text { Percentage of } \\
\text { samples that } \\
\text { do not exceed } \\
\text { SMCLs }\end{array}$ & NA & 57 & NA & NA & 95 & NA & 100 & 100 & 88 & 56 & 100 \\
\hline \multicolumn{12}{|c|}{ Boeuf River near Arkansas-Louisiana State Line (1957-98) ${ }^{3}$} \\
\hline Median & 20 & 30 & 309 & 7.9 & 7.3 & 100 & 34 & 18 & 30 & 40 & 206 \\
\hline 10th percentile & 8 & 10 & 96 & 5.7 & 6.7 & 37 & 5.3 & 8 & $<8.6$ & 9.2 & 96 \\
\hline 90th percentile & 29.8 & 120 & 706 & 10.7 & 8 & 240 & 97 & 38.1 & 164 & 72 & 420 \\
\hline $\begin{array}{c}\text { Number of } \\
\text { samples }\end{array}$ & 145 & 114 & 132 & 92 & 153 & 97 & 131 & 120 & 9 & 9 & 103 \\
\hline $\begin{array}{l}\text { Percentage of } \\
\text { samples that } \\
\text { do not exceed } \\
\text { SMCLs }\end{array}$ & NA & 33 & NA & NA & 92 & NA & 100 & 100 & 100 & 67 & 95 \\
\hline SMCLs & NA & 15 & NA & NA & $6.5-8.5$ & NA & 250 & 250 & 300 & 50 & 500 \\
\hline
\end{tabular}


During this period, the highest monthly average flow occurred during February $\left(619 \mathrm{ft}^{3} / \mathrm{s}\right)$, and the lowest occurred during September $\left(152 \mathrm{ft}^{3} / \mathrm{s}\right)$ (USGS, 2016a). Flow is affected at this site by irrigation withdrawals and interconnected bayous and drainage ditches.

\section{Bayou Macon Subbasin}

Bayou Macon originates north of the Louisiana State line and flows in a general southerly direction along much of the eastern border of the parish. Bayou Macon receives flow from Alligator, Lyon, and Hill Bayous and other tributaries. The average streamflow for Bayou Macon near Delhi (USGS site number 07370000), located south of West Carroll Parish on the eastern border of Richland Parish (fig. 1), was $975 \mathrm{ft}^{3} / \mathrm{s}$ during 1934-92 from a drainage area of $782 \mathrm{mi}^{2}$ (USGS, 2016a). In 2014, $2.01 \mathrm{Mgal} / \mathrm{d}$ were withdrawn from Bayou Macon: $0.60 \mathrm{Mgal} / \mathrm{d}$ for rice irrigation and $1.41 \mathrm{Mgal} / \mathrm{d}$ for general irrigation (Collier, 2018).

\section{Surface-Water Quality}

Water-quality samples were collected from Big Colewa Creek $^{5}$ near Oak Grove (USGS site number 07368500) during 1956-67, Bayou Macon near Kilbourne (USGS site number 07369700) during 1957-91, and Boeuf River near AR/LA State Line (USGS site number 07367700) during 1957-98 (fig. 1) as part of an ongoing program to monitor the State's surface-water resources. These samples were generally within the SMCLs for chloride, sulfate, and dissolved solids (table 4). Median hardness values were within the moderately hard range for Bayou Macon and Boeuf River samples and within the soft range for Big Colewa Creek samples. Median values for dissolved-oxygen concentrations were greater than $7.5 \mathrm{mg} / \mathrm{L}$ in samples from Bayou Macon and Boeuf River. A dissolvedoxygen concentration of $5 \mathrm{mg} / \mathrm{L}$ is considered the minimum value for a diverse population of fresh, warm water biota, including sport fish (Louisiana Department of Environmental Quality, 2008). Dissolved-oxygen samples were not available for the Big Colewa Creek near Oak Grove site. More than 70 percent of Big Colewa Creek samples exceeded the SMCL for $\mathrm{pH}$, whereas more than 90 percent of samples from Bayou Macon and Boeuf River had a pH within the SMCL.

\section{References Cited}

Brantly, J.A., and Seanor, R.C., 1996, Louisiana ground-water map no. 9 Potentiometric surface, 1993, and water-level changes, 1968-93, of the Cockfield aquifer in northern Louisiana: U.S. Geological Survey Water-Resources Investigations Report 95-4241, 2 sheets. [Also available at http://pubs.er.usgs.gov/ publication/wri954241.]

Collier, A.L., 2018, Water withdrawals by source and category in Louisiana Parishes, 2014-2015: U.S. Geological Survey data release, https://doi.org/10.5066/ F78051VM.

Hem, J.D., 1985, Study and interpretation of the chemical characteristics of natural water (3d ed.): U.S. Geological Survey Water-Supply Paper 2254, 264 p., accessed February 20, 2013, at http://pubs.er.usgs.gov/publication/wsp2254.

${ }^{5}$ The National Water Information System refers to USGS site number 07368500 as Big Colewa Bayou near Oak Grove.
Louisiana Department of Environmental Quality, 2008, Environmental Regulatory Code, Title 33, Part IX, Subpart 1: Baton Rouge, Louisiana Department of Environmental Quality, accessed June 9, 2009, at http://www.deq.louisiana.gov/portal/tabid/1674/ Default.aspx.

Louisiana Department of Natural Resources, 2016, Strategic Online Natural Resources Information System (SONRIS): Louisiana Department of Natural Resources database, accessed August 25, 2016, at http://sonris.com/.

Poole, J.L., 1961, Ground-water resources of East Carroll and West Carroll Parishes, Louisiana: Louisiana Department of Public Works, 174 p., 15 pl.

Sargent, B.P., 2011, Water use in Louisiana, 2010: Louisiana Department of Transportation and Development Water Resources Special Report no. 17, 135 p.

Saucier, R.T., 1994, Geomorphology and Quaternary geologic history of the lower Mississippi Valley, v. 1-2: Vicksburg, Miss., U.S. Army Corps of Engineers, 364 p., 28 pls.

Seanor, R.C., and Smoot, C.W., 1995, Louisiana ground-water map no. 6-Potentiometric surface, 1990, and water-level changes, 1974-90, of the Mississippi River alluvial aquifer in northeastern Louisiana: U.S. Geological Survey Water-Resources Investigations Report 95-4146, 2 sheets.

Smoot, C.W., 1988, Louisiana hydrologic atlas map no. 3-Altitude of the base of freshwater in Louisiana: U.S. Geological Survey Water-Resources Investigations Report 86-4314, 1 sheet, accessed November 2, 2011, at http://pubs.er.usgs.gov/ publication/wri864314

Smoot, C.W., 1989, Louisiana hydrologic atlas map no. 4 - Geohydrologic sections of Louisiana: U.S. Geological Survey Water-Resources Investigations Report 87-4288, 1 sheet. [Also available at https://pubs.usgs.gov/wri/1987/4288/plate-1.pdf.]

U.S. Environmental Protection Agency, 2016, Secondary Drinking Water StandardsGuidance for nuisance chemicals, accessed April 13, 2016, at https://www.epa.gov dwstandardsregulations/secondary-drinking-water-standards-guidance-nuisancechemicals.

U.S. Geological Survey [USGS], 2016a, USGS water data for the Nation: U.S. Geological Survey National Water Information System database, accessed November 30, 2016, at https://doi.org/10.5066/F7P55KJN.

U.S. Geological Survey [USGS], 2016b, U.S. Geological Survey Water Resources Cooperative Program-Louisiana Water Use Program, accessed November 28, 2016, at https://la.water.usgs.gov/WaterUse/default.asp.

Whitfield, M.S., Jr., 1975, Geohydrology and water quality of the Mississippi River alluvial aquifer, northeastern Louisiana: Louisiana Department of Public Works Water Resources Technical Report no. 10, 29 p. [Also available at https://la.water.usgs.gov/ publications/pdfs/TR10.pdf.]

This fact sheet has been prepared by the USGS, in cooperation with the Louisiana Department of Transportation and Development (DOTD), as part of a program to document water use, availability, and quality in the parishes of Louisiana. Information on the availability, past and current water use, use trends, and water quality from groundwater and surface-water sources in the parish is presented here. Previously published reports (see References Cited section) and data stored in the USGS National Water Information System (USGS, 2016a) are the primary sources of the information presented here. Special thanks are given to Doug Taylor, Director, and Zahir "Bo" Bolourchi (retired), DOTD Cooperative Program with the USGS.

\section{By Vincent E. White}

\section{For additional information, contact:}

Director, USGS Lower Mississippi-Gulf Water Science Center 3535 S. Sherwood Forest Blvd., Suite 120

Baton Rouge, LA 70816

E-mail: gs-w-lmg_center_director@usgs.gov

Fax: (225) 298-5490

Telephone: (225) 298-5481

Home Page: http://la.water.usgs.gov 